\title{
Information Technology Supports Local Product Going International
}

\author{
Ambar Teguh Sulistiyani ${ }^{1}$, Titis Dewi Anggalini ${ }^{2}$, Kristi Yuliani $^{3}$ \\ atsulis@yahoo.co.id ${ }^{1}$,titisdewianggalini@gmail.com², yuliani.kristi@gmail.com³ \\ Universitas Gadjah Mada
}

\begin{abstract}
The development of information technology has removed limitations between continents, countries and nations. Computer network system becomes the advance invention which was widely open the utilization of information technology. The use of email, electronic data interchange, tele-medicine, virtual office and electronic commerce spread rapidly to all over the world. The new demand of the utilization of information technology for all producer in marketing their goods and services cannot be avoided. Nowadays, global era has changed the distribution and marketing system of goods and services.The positive impact for all good and service produces in local level was the opportunity to go international. Online transaction model was really flexible and practical since it was not limited by place, time or the subject. Thus, this online marketing system should be socialized and implemented by good and service producers based on home industry, Micro Small and Medium Enterprise, Village-Owned Enterprise and cooperative. This article analyzes the application of website to support local product going through world market. The research method was done with online survey on the use of website and electronic commerce towards Micro Small and Medium Enterprises, Village-Owned Enterprises and cooperative.
\end{abstract}

Keywords: Information Technology, Go International, Local Product, Online Marketing, Micro Small And Medium Enterprise, Village-Owned Enterprise, Cooperative.

\section{Introduction}

Globalization currently has a major impact, especially for the economic sector. Open markets were growing without any territorial boundaries between one region and another. This openness leads to perfect competition between market participants. Competition in the free market was indeed very strict. Manufacturers of home-based goods and services (home industry), Micro, Small and Medium Enterprises (MSMEs), Village-Owned Enterprises (BUMDes) and Cooperatives were small and medium-scale producers who must develop promotions in the marketing process for business continuity. Chen and Holsapple [1] stated that e-business can bring an organization (or individual) was prepared to facilitate ebusiness.Marketing through websites was one method that was quite cheap and covers a variety of target groups for both local and foreign buyers. The most common form of marketing using internet media was E-Business also called e-business models [2].In fact, not all people understand technological development, especially the internet. In rural communities, business people who understand internet technology were still very limited. This condition then becomes an obstacle in utilizing the internet network to market local products. 
MSMEs has many obstacles that must be managed carefully. Essentially, the free market has hit MSMEs due to the ease of foreign products to enter Indonesia. This has happened since the European Free Trade Association (AFTA) was launched, which was a visualization of the European Economic Community. This phenomenon has triggered the growing awareness of the Asian community to form the ASEAN Economic Community (AEC). As the AEC was formed, the position of Indonesia was not a producer, buta consumer. Indonesia's large populationhas turned Indonesia into an international market place.Openness of international marketing, which has made it easier for foreign goods to enter the national market, has even penetrated traditional markets. This condition will lead to a sluggish trade in local goods and services. For this reason, marketing innovation efforts were needed, so that at least they can survive or compensate for the global marketing pressures of today. Online marketing was a trend that was growing rapidly in the era of information technology.

\section{Methods}

The methods was qualitative study research method using secondary data analysis. Data collected by analyze documents both online and written reports. The study was conducted on secondary data on MSMEs, cooperatives, and BUMDes that use online marketing. The research especially observe how far the use of online marketing in lifting local products to go international in MSMEs, cooperatives, and BUMDes. Research was focused on all city and district in DIY. This paper presents actual data including quantitative data related to internet use by village institutions. Where previous journals limited to qualitative data.

\section{Results}

\subsection{Identification of Marketing Problems of Local Products}

First problem that was often faced by small business owners was the weak market penetration and little coverage of the marketing area. Therefore, a good, specific and targeted marketing strategy was needed to advance the business. Second problem that should be handled was the improvement of market confidence. The quality and the sustainability value of products needs to be developed. Third problems of MSMEs, BUMDes and Cooperatives were also in the realm of limited distribution capabilities. The need for distribution channels was increasing to reach the market or consumers. Fourth, Non-competitive prices will weaken the marketing of local products and prevent themfrom going international. Marketing of local products was faced with an abundance of imported goods on a large scale, at very cheap prices.

The predetermined prices also help assign product positioning, consumer reactions to alternative prices, product costs, competitor prices, and other legal and ethical factors improve management flexibility in pricing. Based on the identification of marketing problems, one problem that was often faced by MSMEs, BUMDes and Cooperatives in Indonesia was less familiarity with market characteristics. Mohammed et.all[3]stated that internet marketing determines the development of strategies faster in cycle time. Dann and Dann [4] also mentioned that marketing strategies using the internet have advantages in cost cutting and efficiency. 


\subsection{Unraveling IT Applications in Local Products Marketing}

MSMEs, BUMDes and Cooperatives cannot deny the presence of IT. Information systems reduce processing time, improve communication, and help make decisions. Internet marketing provides improvement in marketing business accountability and integration of marketing strategies with business operational strategies[3].According to Solomon [5] several alternatives can be done, namely segementing, targeting and positioning.Market segmentation (segmenting) was the process of dividing markets into smaller groups, based on consumer characteristics.Therefore, segmentation was an important process for identifying buyers needs and desires in the entire market. Mohammed et.al [3] stated that internet marketing has an effect on improving segmentation. Determination of target markets (targeting) was the process of evaluating and selecting each segment to be served by MSMEs, BUMDes and Cooperatives. Through the determination of the target market, MSMEs, BUMDes and Cooperatives can obtain certain added values. Positioning as a form of management of two combined activities, which were marketing activities on one hand, and on the other was an effort to fulfill the needs and desires of each target market.

By using IT, MSMEs, BUMDes and Cooperatives can observe their competitors. Competitors with similar products and services can be identified from online markets. These online markets can display local, national and international product and service preferences. An online promotion strategy was developed to expand the marketing scope of local products. Dann and Dann[4]mentioned that marketing strategies using the internet provide superior access, and promotional advantages. In the end, any promotional activities cannot work effectively if the internal parties do not pay attention to the performance quality factors of MSMEs, BUMDes and Cooperatives. With product quality, supported by an effective IT communication system, marketing activities can run sustainably.

\subsection{Best E-Marketing Practice for Local Products}

The Government through the Ministry of Communication and Information continues to appeal to business people such as MSMEs, BUMDes, and Cooperatives to 'go online' which means conducting a marketing system with internet networks or technology. This IT-based marketing system can also raise local products to go international. Some examples of the IT use practice in product marketing can be seen from several government policies. In DIY there were several local product marketing policies as follows: The e-smart SMI program was developed as a virtual media for the centers of Small and Medium Industries (SMI). According to Khan [6] E-commerce could deliver a significant benefit. E-commerce was also a business suggestion that can provide a fast and appropriate place for transactions. The development of branding was also presented in internet marketing. Market access becomes increasingly developed with e-SMART SMI, since the market access improves rapidly. Promotional, sales and marketing operational costs can be saved.

Relatively similar thing was developed by Kulon Progo Regency, to support the marketing of local products. Since 2017, the Government of Kulon Progo Regencyhas provided an obligation to "Go-Online". The discourse was intended to encourage business people to market their products online. Some help regarding online marketing was also in process. Some of the assistance include socialization and training of website use and providing websites for business people. One of the websites currently used was https://belabeliku.com/. There were several services offered on the web: free shipping on all orders (worldwide), 
money back guarantee, lowest price guarante (special discount), 24 hours online support. There were accounts that were distinguished as sellers and buyers. However, unfortunately there was no detailed explanation regarding the service. Also, this website has not run optimally which was shown by several links that were not yet active.

In Sleman Regency there were many MSMEs doing online marketing. The Government of Sleman Regency supports MSMEs, BUMDes and Cooperatives to conduct online marketing training. All learning facilities and infrastructure related to online marketing were provided by the government. This greatly helps the advancement of local product marketing so that some products can penetrate the international market. The export of pondoh zalacca and dragon fruit can proceed well in the Asian market. One innovation of the Sleman District Government's programs was the SME Corner. The SME Corner was a consultative institution for SMEs in Sleman Regency that was a collaboration between the Official of Cooperatives, Small and Medium Enterprises of Sleman Regency and PLUT (Integrated Business Service Center) DIY. This program aims to facilitate and assist SMEs in the form of consultations related to institutional aspects, business management, business strategy, HR management, production, access to finance, product branding and development of market networks and mastery of information technology.

In Bantul Regency, the growth of MSMEs has become very rapid. In 2011-2016, MSMEs in Bantul Regency increased by $40 \%$ to around 140,000 SMEs. The increasing number of MSMEs marks increasingly fierce market competition. Every MSME must be able to carry out a marketing strategy in a more efficient manner. On the other hand, the Government of Bantul Regency also has an obligation to facilitate these business actors. The Government of Bantul Regency provides good support to build online markets for several MSMEs. Even the Head of the Bantul Village also conducts business cooperation for online marketing. Several internet marketing workshops and training have been conducted in Bantul Regency. Theferoe, MSMEs, BUMDes and Cooperatives in Bantul Regency were ready to push local products to go international. Some innovation programs to support online marketing have been carried out including Rumah Kreatif, Kampung Digital UKM, ECommerce, and Pelayanan IUMK Melalui Satu Pintu.

The Government of Gunungkidul Regency has proclaimed the development of internet marketing. Many trainings and workshops were also held so that all local products could be included in broader marketing. There was a marketing school program with a menu of internet marketing learning organized by the government. However, budget constraints were still an obstacle to the uneven development of all MSMEs in Gunungkidul Regency. The total number of MSMEs in Gunungkidul Regency was around 38,000 MSMEs. In the future, the Gunungkidul Regency Government needs to consider a form of assistance to reach more efficient online marketing to cover all MSME, BUMDes, and cooperatives business actors in Gunungkidul Regency.

In the city of Yogyakarta, $75 \%$ of MSME actors have done marketing online. This number was dominated by business people who join the Regional National Craft Council (Dekranasda) of Jogja. In other words, there were several MSMEs that do not have online access. The government then tried to embrace all MSMEs to develop their marketing online by making an application that also supports the idea of Jogja Smart City. The government was preparing an application for marketing MSMEs products, namely "Gandeng Gendong Nglarisi". Initially this program that aims to improve the welfare of MSMEs in Yogyakarta was done by purchasing products by the municipal government to meet the consumption needs through the application. However at this time, the program and the application were developed so that consumers could come from the wider community. The products available were also no 
longer limited to culinary products but were being developed to include handicraft products. Data collection on MSMEs was still ongoing. Five elements involved in this program, namely the Yogyakarta City Government, Universities, Corporations, Villages, and Communities. The percentage online marketing user every city and districts presented in fig.1.

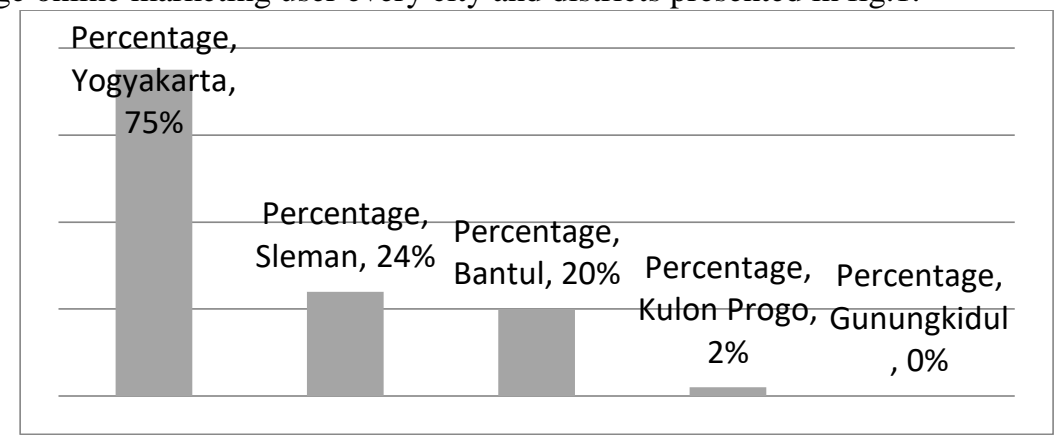

Fig. 1.The Precentage Online Marketing User in DIY

MSMEs in Yogyakarta City that use $75 \%$ online marketing [7]. In Sleman there were 1000 SMEs from 4192 (24\%) who have used online scanners. In Kulon Progo there were 200 smart users for online from about 16.000 MSMEs (2\%) [7]. In Bantul around 20\% of MSMEs use online banking. While in the Gunung Kidul in the level of introduction and training. From explanation before, Yogyakarta City was the most advanced in using online marketing. While the slowest was Gunungkidul district. Community patterns also influence marketing patterns in each region. The Yogyakarta City, which was an urban area, tends to be very literate in information technology. While rural areas like Gunungkidul district were still very comfortable with traditional marketing patterns. The number of tourist visitors who come to Gunung Kidul Regency, which was famous as a natural tourism area, was also the reason for the people of Gunungkidul Regency choose traditional marketing. Many sellers were already comfortable sold their product around the tourist area rather than use an online method that the process was not straight forward. The number of tourists in 2016 compared to 2013 increased to $222 \%$. The number of tourists in Gunungkidul Regency was presented in fig. 2[8].

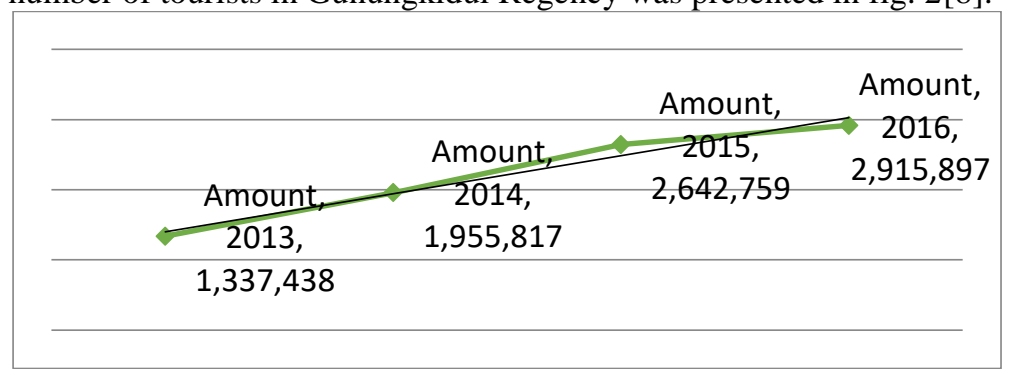

Fig. 2.The Number of Tourist in Gunungkidul Year 2013-2016

To improve the capabilities of MSMEs, BUMDes and Cooperatives in IT-based marketing, the roles of related stakeholders were required. In addition to the government, universities, corporations and communities should be able to help develop IT-based marketing. The realization of stakeholders' cooperation will go smoothly by the protection of legal force, through the MoU. Efforts to expand the use of IT-based marketing in MSMEs, BUMDes and Cooperatives require advocacy from stakeholders, both in facilitation, research, modeling and application of technology, and marketing cooperation. 


\section{Conclusion}

There has been awareness of MSMEs, BUMDes and Cooperatives internally on the importance of developing IT-based marketing. IT-based marketing was useful for business to survive amid tight market competition, and to publicize local goods/services locally and internationally. With the help of internet technology, marketing local products becomes more efficient with wider consumer targets. The DIY Government encourages and facilitates MSMEs, BUMDes, and Cooperatives to Go Online. Five Regencies/City in DIY have been active in encouraging business actors to utilize IT. There were various methods and stages taken by the regencies/cit in empowering MSMEs, BUMDes and Cooperatives to go international. Differences in regencies/city action policies and programs show the government's priorities and capacity. However, all this has shown the magnitude of the government's commitment to deliver local products to go international.Efforts to develop ITbased marketing include the need to increase stakeholders' initiative and participation. For this reason, a cooperation contract between local governments and stakeholders was needed. These various elements must be able to work together to support each other. The government can provide the required facilitation. Universities can develop models and marketing media through their research. Corporations can provide opportunities for MSMEs, BUMDes, and Cooperatives to market their products. The community can be a place to support and share information among members in developing IT-based marketing.

Acknowledgments.Researchers would like to thank Faculty of Social and Political Sciences, Universitas Gadjah Mada and Public Policy and Management Departement, Universitas Gadjah Mada for provide financial support fot this paper. The researcher was also grateful to all those who have supported and participated in the research process.

\section{References}

[1] Chen, Liang and Clyde W. Holsapple, (2013), E-business adoption research: state of the Art,Journal of Electronic Commerce Research, 14YESSE( 3), 261-286.

[2] K, Semen Son, (2015), An analysis of e-business research topics. Proceedings of INTCESS152nd International Conference on Education and Social Science, 2-4 February 2015- Istanbul, Turkey, 321-331.

[3] R. A. Mohammed, Internet marketing: Building Advantage In A Networked Economy, 2nd ed. New York: McGraw-Hill, 2003.

[4] S. Dann and D. S, Internet Marketing. Brisbane: John Wiley \& Sons, 2001.

[5] M. L. Solomon and E. W. Stuart, Marketing, 3th Edition, 3rd ed. New Jersey: Pearson Education-Prentice Hall, 2003.

[6] Khan, Abdul Gaffar. (2016). Electronic Commerce: A Study on Benefits and Challenges in an Emerging Economy, Global Journal of Management and Business Research: B Economics and Commerce, 16 (1 Version 1.0 Year 2016).

[7] Kementerian Koperasi dan Usaha Kecil dan Menengah Republik Indonesia, "Paparan Rakornas Yogyakarta 2018 - DIY,” in Kementerian Koperasi dan Usaha Kecil dan Menengah Republik Indonesia, Jakarta: Kementerian Koperasi dan Usaha Kecil dan Menengah Republik Indonesia, 2018.

[8] B. P. S. Gunungkidul, Gunungkidul Dalam Angka. Yogyakarta: Badan Pusat Statistik Gunungkidul, 2018 